\title{
歯性上顎洞炎の手術療法
}

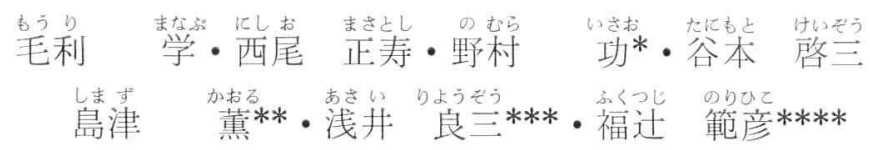

I 、緒言

上顎洞㐘槽瘦孔を有する歯性上顎洞炎が慢性化すると，上㴿洞根本手術に加えて瘻孔閉鎖術が必 要である.かかる症例に対して，われわれはNeumann 粘膜切離法を用いて洞炎手術と瘦孔閉鎖術 を一次的に施行している.

Neumann 法は歯槽膿漏症の治療法として考案され歯科領域では広く利用されている。本法は洞 歯槽癭孔の閉鎖を洞炎の手術と一次的に行ない得る利点があり, 耳鼻科医も大いに用うべき切開法 であると考光報告する次第である.

\section{Neumann 切離法}

手術器具

粜周病科では特殊な膿漏メスが歯頸部の切開 に使用されるが，替刃尖刃で十分である。剝離 飞は七浦式骨膜粘膜剝離子が便利である。（等 真 1 )

麻醉

主として局所麻醉下に施行する。上顎洞炎手 術における通常の方法に，切開を予定した根尖 近くの歯肉に煩舌両側から浸潤麻酔を行なう。

切開 (図 1)

近心は中切歯で遠心は瘦孔を越えたととろで

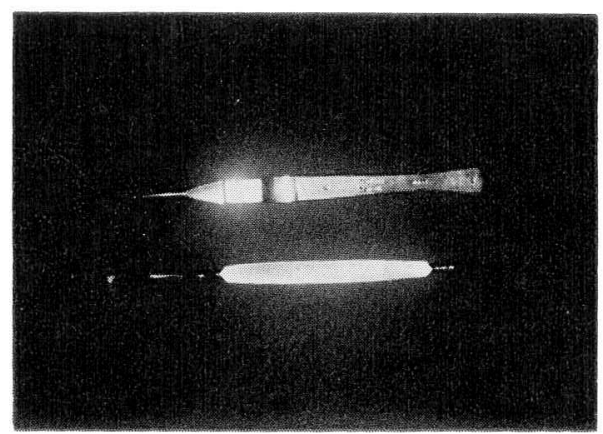

写真 1 上: 膿漏メス

下：七浦式骨膜粘膜剝離子

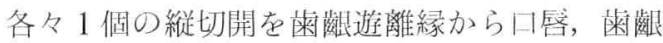
移行部を越えた部位までのばす。この2つの縦 切開の間を幽頸部に沿って，近心から切開をは じめ瘦孔周井在通って邀心の縦切開と連絡させ る.かくして歯䟠者骨膜とともに 1 個の弁とし て剝離举上する。 犬菌窝在露出して以下の操作 は洞炎の手術と同様である(図 2 ), 瘦孔周国の
㐘槽骨は十分に䭁爬し，必要であれば米槽骨の 一部を除去する。この操作が極めて大切であ る.

縫合（図 3，4）

縫合に際し緊張があれば挙上している弁の基 底で骨膜に横切開在加光，緊张をなくして打

Surgical Treatment of Odontogenic Maxillary Sinusitis.

Manabu Mohri, Masatoshi Nishio, Isao Nomura, Keizo Tanimoto, Kaoru Shimazu, Ryozo Asai and Norihiko Fukutsuji.

* 大阪橿科大学耳鼻咽喉科教室

** 大阪歯科大学第 2 口腔外科教室

***兵庫医科大学耳鼻咽喉科教室

****神戸大学耳鼻咽喉科教室 


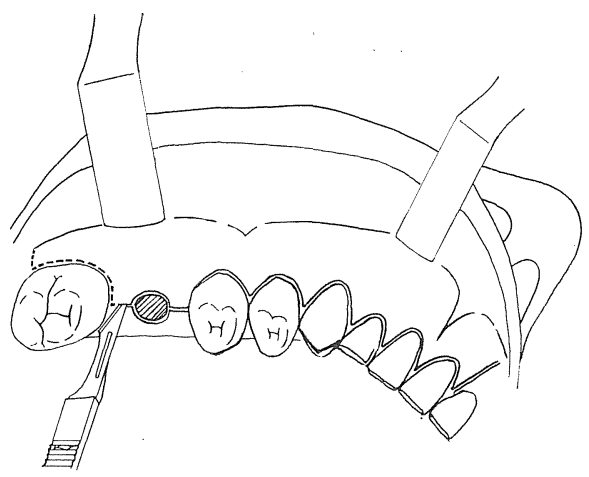

図 1

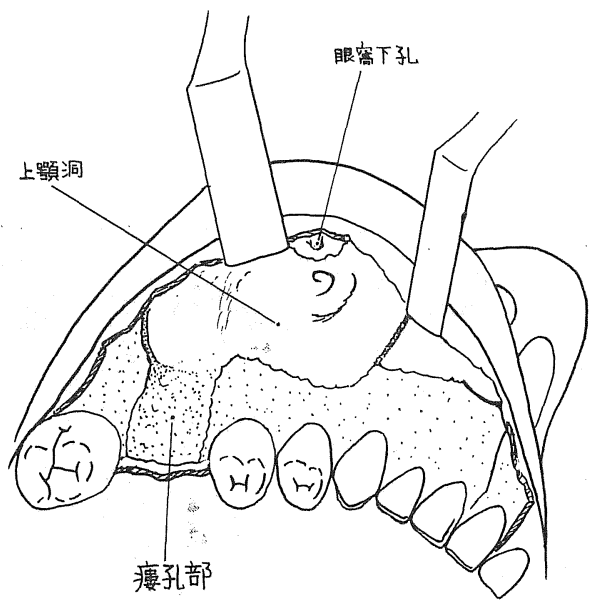

図 2

く、縫合は洞歯槽瘻孔からはじめる。瘻孔部は

III. 症

Neumann 法を用いて28例の歯性上顎洞炎に 対して手術を施行した. 各症例は表 2 の部位に 洞蒾槽瘦孔を有する. 1 例に第 2 小曰歯と第 1 大曰歯との 2 歯におよぶ大さな瘦孔を認める. X線検査では患側上顎洞の混濁，造影検査では 洞粘膜の著しい肥厚を示している. 臨床経過と 他覚的所見加ら瘻孔関鎖と洞炎手術の適応と考 えられる。

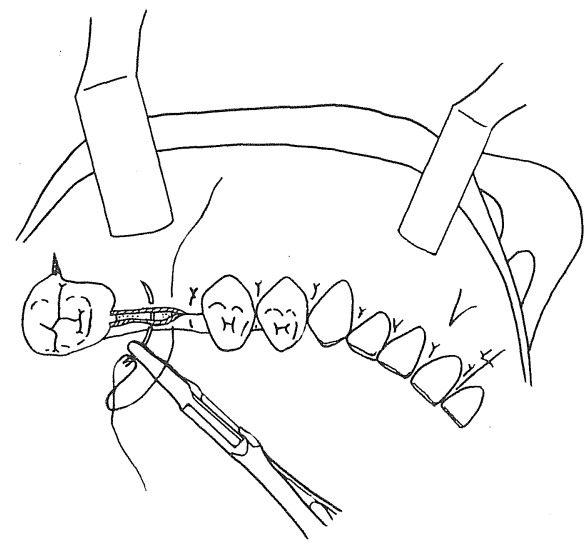

図 3

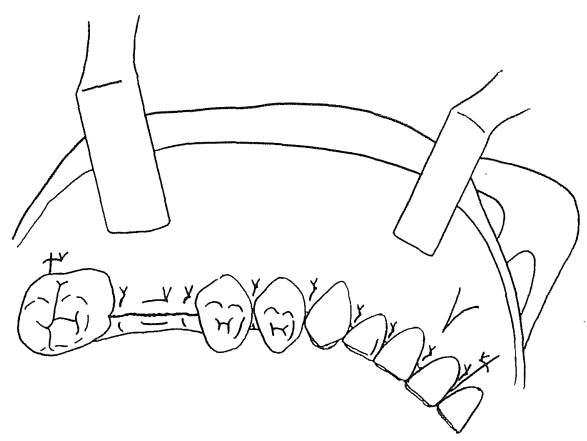

図 4

mattress suture を施す。蒾肉の縫合は歯間乳 頭部を唇舌的に縫合する。

例（表 1)

28例の成績は表 1 に示す如くで，26例は良好 な結果を得ている。乙のうち 1 例は口蓋粘膜升 を同時に併用し瘦孔閉鎖を行なっている. 失敗 例は 2 例で術後 5 日, 6 日目に同部に再穿孔を きたし，それぞれ 1 力月後，2 力月後に口盍弁 を使用して瘻孔開鎖を施行している. 全症例と も術後の歯牙に対する影響は皆無であり，何等 の異常も認めていない. 
表

\begin{tabular}{|c|c|c|c|c|c|c|}
\hline No. & 年令 & - 性 & 主 & 瘻 孔 部 位 & 転 帰 & 備 \\
\hline 1 & 40 & $\hat{o}$ & 徳 臭 鼻 漏 & 右第一大曰歯 & 穿孔 & 2 ケ月後口蓋弁閉鎖 \\
\hline 2 & 32 & 우 & 頭重 感 & 右第三大目歯 & 治ゆ & \\
\hline 3 & 58 & 우 & 瘻孔より膿 & 左第一大四歯 & " & \\
\hline 4 & 51 & 우 & " & " & " & \\
\hline 5 & 71 & $\hat{o}$ & 瘦孔周囲痛 & 右第一大田歯 & " & \\
\hline 6 & 44 & 우 & 煩 部異 和感 & 左第一大四歯 & " & \\
\hline 7 & 31 & 우 & 霋孔ょり膿 & 右第二大四歯 & " & \\
\hline 8 & 63 & 우 & 鼻より食物流出 & 左第一大曰歯 & " & \\
\hline 9 & 41 & 令 & 鼻 & " & " & 抜歯窩プロテーゼ \\
\hline 10 & 22 & 우 & 悪 臭 鼻 漏 & 右第二大四歯 & " & 1 か月後口蓋弁閉鎖 \\
\hline 11 & 29 & 우 & 瘻孔より膿 & 右第一大曰歯 & " & \\
\hline 12 & 38 & $\hat{o}$ & 煩 部 痛 & 左第一大四歯 & " & \\
\hline 13 & 45 & 令 & 瘻孔より膿 & " & " & \\
\hline 14 & 41 & 全 & 頭 重 感 & 左第二大曰歯 & 穿孔 & \\
\hline 15 & 62 & $\hat{o}$ & 瘦孔より膿 & 右第二大目歯 & 治ゆ & \\
\hline 16 & 26 & 令 & 瘦孔より膿 & 左第一大曰歯 & 治ゆ & \\
\hline 17 & 45 & 令 & " & 右第二大曰歯 & " & \\
\hline 18 & 40 & 令 & " & 右第一大曰歯 & " & \\
\hline 19 & 27 & $\hat{\jmath}$ & " & 左第一大田歯 & "1 & \\
\hline 20 & 37 & $\hat{\jmath}$ & " & 右第一大曰歯 & " & \\
\hline 21 & 18 & 令 & " & " & " & \\
\hline 22 & 59 & 今 & " & 左第一、二大曰歯 & " & \\
\hline 23 & 23 & 㑒 & " & 右第三大曰霜 & " & \\
\hline 24 & 54 & 令 & " & 右第一大四歯 & " & \\
\hline 25 & 23 & 우 & " & " & " & 口盍弁同時併用 \\
\hline 26 & 27 & 우 & " & 左第一大四歯 & "1 & \\
\hline 27 & 49 & 令 & " & " & & \\
\hline 28 & 37 & $\hat{\delta}$ & " & 右第一大巨歯 & & \\
\hline
\end{tabular}

表 2 瘻孔部位

\begin{tabular}{c|c}
\hline 第一大曰歯 & 21 \\
第二大曰歯 & 5 \\
第三大日歯 & 2 \\
第二小曰歯 & 1
\end{tabular}

IV. 総

Neumann 法 ${ }^{1)}$ は歯槽膿漏症の治療法として 考案された粘膜切開法で歯肉剝離搔爬術 flap operation と称される。

本法は先述の如く歯性上顎洞炎で洞蒾槽㾞孔 を有する場合，洞歯槽瘦孔の閉鎖を洞炎の手術 と一次的に実施できる。また，歯性上顎洞炎の
括

手術時抜蒾により洞菌槽瘻孔交残す可能性のあ る場合，術後性上顎囊腫で顔面壁の骨吸収が著 しく通法の横切開では口腔前庭に洞瘦孔を残す 可能性がある場合にも応用し得る ${ }^{2)}$. 縫合の複 雑さを除けば術後歯牙に後遺症を残さない点も 優れた方法である. 
本法における成功の鍵は, 㾇孔周井の歯槽骨＼cjkstart加え十分な減張をはかる点にある.

の徹底した掻爬と升の基底部の骨膜に横切開を

$$
\text { V. 結 語 }
$$

Neumann 法は歯性上顎洞炎の手術療法において洞炎手術と洞歯槽㾞孔閉鎖術を一次的に行ない 得る利点があり，用うべき切開法と考える.

本論文の要旨は第13回鼻副鼻腔学会において発表した。

文献

1) Neumann, R. : Atlas der radikal, chirurgischen

Vol. 2，80，昭48（1973）

Behandlungen der Paradentosen. Hermann Mersser, Berlin, 1926.

2) 浅井良三, 毛利 学, 西尾正寿, 福辻範彦 : 上䫓 洞炎根本手術における 粘膜切開法 — NeumannWassmund 切離法の紹介一, 兵庫医科大学誌

(原 稿 到 着：昭和49年10月21日 別刷請求先: 毛利 学 歨540大阪市東区京橋 1 丁目 4 番地 大阪崡科大学耳鼻咽喉科学教室 